\title{
Сучасний погляд на проблему застосування засобів фізичної реабілітації при артроскопічних оперативних втручаннях у хворих із ушкодженням передньої схрещеної зв'язки
}

\author{
УдК: 616.72-018.38-089.168:615.83
}

\section{А. П. Русанов}

ДУ «Інститут травматології і ортопедії НАМН України», Київ, Україна

\begin{abstract}
Резюме. Мета: систематизувати та узагальнити науково-методичні знання і результати практичного досвіду фізичної реабілітації хворих після реконструкції передньої схрещеної зв'язки при артроскопічних оперативних втручаннях. Методи: теоретичний комплексний аналіз і синтез даних науково-методичної літератури та джерел мережі Інтернет. Результати. Проаналізовано методи лікування декомпенсованої передньої нестабільності колінного суглоба, спричиненої розривом передньої схрещеної зв'язки. Весь післяопераційний реабілітаційний період перебігає на тлі етапних процесів інкорпорації трансплантату в кісткових тунелях. Саме стадійність відновлення трансплантату є основою для виділення різних періодів реабілітації. Розглянуто сучасні підходи до застосування засобів фізичної реабілітації при артроскопічних оперативних втручаннях у хворих з ушкодженням передньої схрещеної зв'язки. Висновки. Лікування таких хворих необхідно проводити з обов'язковим урахуванням анатомо-функціональних особливостей, використовувати методи раннього і повноцінного відновлення пошкоджених структур суглоба, прагнути до підбору відновлювальних операцій, що не вимагають іммобілізації суглоба. Крім цього, адекватні відновні комплекси, що враховують тип фіксації трансплантату, функціональні особливості ураженої кінцівки й інші чинники, у тому числі ступінь порушення функції колінного суглоба, розроблено далеко не для всіх випадків ушкоджень та їх наслідків. На сьогодні актуальною є розробка програм фізичної реабілітації, що враховують тип фіксації використаного трансплантату при артроскопічних оперативних втручаннях.
\end{abstract}

Ключові слова: колінний суглоб, реабілітація, відновлення, ушкодження передньої схрещеної зв'язки.

Резюме. Цель: систематизировать и обобщить научно-методические знания и результаты практического опыта физической реабилитации больных после реконструкции передней крестообразной связки при артроскопических оперативных вмешательствах. Методы: теоретический комплексный анализ и синтез данных научно-методической литературы и источников сети Интернет. Результаты. Проанализированы методы лечения декомпенсированной передней нестабильности коленного сустава, вызванной разрывом передней крестообразной связки. Весь послеоперационный реабилитационный период проходит на фоне этапных процессов инкорпорации трансплантата в костных туннелях. Именно стадийность восстановления трансплантата является основой для выделения различных периодов реабилитации. Рассмотрены современные подходы к применению средств физической реабилитации при артроскопических оперативных вмешательствах у больных с повреждением передней крестообразной связки. Выводы. Лечение таких больных необходимо проводить с обязательным учетом анатомо-функциональных особенностей, использовать методы раннего и полноценного восстановления поврежденных структур сустава, стремиться к подбору восстановительных операций, не требующих иммобилизации сустава. Кроме этого, адекватные восстановительные комплексы, учитывающие тип фиксации трансплантата, функциональные особенности пораженной конечности и другие факторы, в том числе степень нарушения функции коленного сустава, разработаны не для всех случаев повреждений и их последствий. На сегодняшний день актуальной является разработка программ физической реабилитации, учитывающих тип фиксации использованного трансплантата при артроскопических оперативных вмешательствах. 
Ключевые слова: коленный сустав, реабилитация, восстановление, повреждения передней крестообразной связки.

\begin{abstract}
Objective: systematization and generalization of scientific-methodical knowledge and the results of practical experience in physical rehabilitation of patients after anterior crucial ligament reconstruction in the course of arthroscopic interventions. Methods: theoretical complex analysis and synthesis of data of scientific-methodical literature and Internet sources. Results. The methods of treatment of decompensated anterior instability of the knee joint, caused by the rupture of the anterior crucial ligament, are analyzed. The entire postoperative rehabilitation period runs on the background of the progressive processes of incorporation of the graft in bone tunnels. It is the stage character of graft restoration that is the basis for outlining different periods of rehabilitation. The modern approaches to usage of physical rehabilitation means in the case of arthroscopic surgical interventions in patients with damaged anterior crucial ligament are considered. Conclusions. The treatment of patients with damaged anterior crucial ligament should be carried out with the obligatory consideration of anatomical and functional features, usage of methods for early and complete recovery of damaged joint structures, search for recovery operations that do not require joint immobilisation. In addition, adequate restorative complexes that take into account the type of graft fixation, functional features of the affected extremity and other factors, including the degree of knee joint function impairement, are far from being developed for all cases of injuries and their consequences. Today, the development of physical rehabilitation programs that take into account the type of graft fixation used in arthroscopic surgical interventions is rather relevant.
\end{abstract}

Keywords: knee joint, rehabilitation, recovery, anterior crucial ligament injuries.

Постановка проблеми. Патогенез нестабільності колінного суглоба можна представити у вигляді послідовних ланок патологічного ланцюга: травма - ушкодження структур підсистеми - порушення біомеханіки - розвиток нестабільності - дегенеративно-дистрофрічний процес [12]. А. К. Орлецкий (1998) [8] вважає, що після розриву схрещених зв'язок їх механорецептори не можуть наповнити центральну нервову систему афрферентною импульсацією про положення у суглобі, що обумовлює відсутність нейросенсорного контролю нервово-м'язової координації. Внаслідок цього може розвинутися рецедивуюче пошкодження активних стабілізаторів і інших структурних елементів капсульно-зв'язкового апарату, що під час тривалого процесу спричинює нестабільність колінного суглоба і прогресування артрозу. Все перераховане вище призводить до збільшення термінів госпіталізації, зниження якості життя, зміни професії та нерідко до інвалідизації.

Ушкодження капсульно-зв'язкового апарату колінного суглоба $€$ одними з найпоширеніших у травматології. Найчастіше уражаються його медіальні структури або передня схрещена зв'язка (ПСЗ) - від 43 до 80 \% випадків, поєднання розривів передньої і задньої схрещених зв'язок трапляється у 13-59 \% випадків.

Донині немає єдиної думки про терміни відновлення зв'язок. Незважаючи на заклики деяких травматологів [12] проводити оперативне відновлення пошкоджених зв'язкових структур якомога раніше, інші автори рекомендують здійснювати активне оперативне втручання вже на тлі хронічної нестабільності колінного суглоба.
Відтворення багатофрункціонального, складного за будовою зв'язкового апарату колінного суглоба $\epsilon$ актуальною проблемою сучасної травматології та ортопедії. Для відновлення схрещених зв'язок застосовують внутрішньосуглобові, позасуглобові і комбіновані оперативні втручання з використанням ауто-, аллотрансплантатів і синтетичних матеріалів [5, 12].

Взяття у якості аутотрансплантату сухожилка півсухожилкового м'яза спричинює додаткове пошкодження стабілізуючого апарату колінного суглоба. Необхідність тривалих термінів іммобілізації для досягнення зрощення і перебудови сухожилкової тканини призводить до атросрії м'язів стегна, гомілки, обмеження обсягу рухів у колінному суглобі внаслідок артрофріброзу, що вимагає додаткового і тривалого реабілітаційного лікування $[5,9,12]$.

До переваг аллопластики можна віднести відсутність донорської рани і всіх пов'язаних 3 цим ускладнень, скорочення часу оперативного втручання і зниження його травматичності, варіабельність розмірів [7, 12]. До загальних недоліків застосування ауто- і аллотрансплантатів належить також прогнозоване ослаблення тканин після імплантації внаслідок некрозу, реваскуляризації, яке настає після часткової резорбції трансплантату зв'язки. Ослаблення тканин починається через 2-3 тиж. після операції, коли відбувається реваскуляризація, і триває 9-12 міс., поки не завершиться процес клітинного заселення і ремоделяції, що призводить до міцності тканин, близької до нормальної міцності схрещених зв'язок. У цьому часовому проміжку трансплантат 
зв'язки залишається відносно уразливим до зайвого навантаження, що вельми актуально при активній реабілітації в післяопераційний період $[1,12]$.

Необхідність тривалих термінів іммобілізації веде до розвитку ряду патофрізіологічних процесів, що обумовлюють зниження кровотоку i появу дегенеративно-дистрофрічних процесів у м'язах і тканинах кінцівки. Знижується здатність м'язів скорочуватися, зменшується їх еластичність. Волокна сухожилків втрачають свою прямолінійність, коротшають. Між сухожилками і листками сухожилкових піхов утворюються спайки. Гіаліновий хрящ стоншується, заміщується волокнистим хрящем і кісткою. Із синовіальної оболонки в порожнину суглоба вростає сполучна тканина - паннус. Суглобова капсула зморщується, трансформується в сполучну тканину, утворюється фріброзний анкілоз [12, 15]. При тривалій іммобілізації колінного суглоба виявляються такі закономірності: його фріксація впродовж 3 тиж. спричинює зниження об'єму чотириголового м'яза стегна на $2 \%$, відновлення його об'єму вимагає 6 тиж.; фріксація протягом 12 тиж. обумовлює зниження об'єму чотириголового м'яза на $9 \%$, для відновлення необхідно 20 тиж. [12]. Зі сказаного випливає, що лікування хворих із внутрішньосуглобовими ушкодженнями необхідно проводити з обов'язковим урахуванням анатомо-функціональних особливостей, використовувати методи раннього і повноцінного відновлення пошкоджених структур суглоба, прагнути підбирати відновлювальні операції, що не вимагають іммобілізації суглоба [7, 12].

Застосування синтетичних ендопротезів зв’язок усуває ряд проблем: дозволяє використовувати прискорені програми відновлення 3 функціональними ранніми навантаженнями, виключає ризик зараження вірусними інфекціями [12]. Умови для агресивної реабілітації такі: висока міцність імплантата зв'язки, стійка внутрішня фріксація, ізометричне розташування в суглобі, контроль за післяопераційними септичними ускладненнями, контроль за передньозаднім зміщенням, відсутність шкідливих ефектів іммобілізації, профрілактика ригідності суглоба і потенціювання мускулатури, профрілактика контрактури м'язів-згиначів стегна, відновлення нормальної ходи і повернення травмованого пацієнта до трудової та спортивної діяльності. Порівняно 3 використанням аутотрансплантатів скорочується час оперативного втручання і спрощується його технічне виконання. Рання активізація м'язів призводить до поліпшення трофріки кінцівки, розсмоктування гематом, прискорення консолідації кісткових каналів і переломів виростків (при поєднаних пошкодженнях), відновлення фрізіології суглоба. Рухи в суглобі підтримують тонус м'язів, перешкоджають їх атрофії, не дають утворюватися спайкам, призводять до нормалізації кровотоку, сприяють активізації регенерації.

Таким чином, в основі більшості функціональних порушень, що виявляються у хворих після пластики ПСЗ, лежать місцеві прояви відповідної реакції організму на патологічний процес та зниження опороспроможності кінцівки, що спричинює зміни в тканинах суглоба - фрормування рубців, дегенерацію суглобового хряща, гіпотрофію м'язів. Слід зазначити також, що весь післяопераційний реабілітаційний період перебігає на тлі етапних процесів інкорпорації трансплантату в кісткових тунелях та його перебудови (лігаментизації). Саме стадійність відновлення трансплантату $є$ основою для виділення різних фраз реабілітації, розділених на тижні, що спрощує завдання динамічного спостереження за прооперованими хворими в процесі реабілітаційного лікування.

Зв'язок роботи 3 науковими планами, темами. Робота виконувалася за темою Державної установи «Інститут ортопедії та травматології НАМН України»: «Розробити систему етапної реабілітації хворих з ушкодженнями внутрішньосуглобових структур колінного суглоба після артроскопічних оперативних втручань» (номер держреєстрації 0113U001124).

Мета дослідження - систематизувати та узагальнити науково-методичні знання і результати практичного досвіду фрізичної реабілітації хворих після реконструкції ПСЗ при артроскопічних оперативних втручаннях.

Методи дослідження: теоретичний комплексний аналіз та синтез даних науково-методичної літератури та джерел мережі Інтернет.

Результати досліджень та їх обговорення. За даними літератури, проблема лікування пацієнтів з патологією колінного суглоба залишається актуальною та однією з найскладніших у травматології та ортопедії. Розриви схрещених зв'язок колінного суглоба становлять від 7,3 до $62 \%$ всіх ушкоджень капсульно-зв'язкового апарату [4].

Одним із заходів, що здатний покращити результати лікування хворих при пошкоджені капсульно-зв'язкового апарату колінного суглоба, може стати впровадження чітких поетапних реабілітаційних дій [3].

Лікувальна дія фрізичних реабілітаційних вправ здійснюється за рахунок основних механізмів: тонізуючого впливу фрізичних вправ, трофрічної дії фрізичних вправ, механізму фрормування 
тимчасових та постійних компенсацій і механізму нормалізації функцій колінного суглоба.

Наявні комплекси фрізичної реабілітації при повному та частковому розриві зв'язок колінного суглоба ще недосконалі та неповні, тому пошук нових комплексних програм фрізичної реабілітації таких хворих $\epsilon$ актуальною проблемою, яка потребує наукового вирішення. У зв'язку з цим, подальші дослідження з цієї тематики мають певні перспективи.

Оцінка клінічного стану хворих з ушкодженням ПСЗ традиційно проводиться з обліком двох основних факторів: больових відчуттів і функціональних можливостей ураженого суглоба й нижніх кінцівок у цілому. Для об'єктивної оцінки клініко-фрункціонального статусу пацієнтів запропоновано численні клінічні, біомеханічні й електроміографрічні методики. Однак жодна з них не дозволяє одержати інформацію про те, наскільки травма обмежує життєдіяльність хворого. Одним із нових критеріїв ефективності лікування, що набули останніми роками значного поширення, $\epsilon$ дослідження показників якості життя.

Дослідження показників стабілометрії та ізокінетичної динамометрії при пошкодженнях, консервативному і оперативному лікуванні розривів ПСЗ колінного суглоба показали, що пошкодження цієї зв'язки обумовлює порушення постурального контролю [14]. Нездатність розтягнутої або пошкодженої зв'язки забезпечити адекватний зворотний зв'язок може призвести до втрати фрункції та дегенерації колінного суглоба [14]. Виявлено зв'язок між порушенням стабільності колінного суглоба в сагітальній площині і білатеральним порушенням статокінетичної стійкості у спортсменів з ізольованими давніми пошкодженнями ПСЗ. Порушення пропріоцептивних зв'язків із центральною нервовою системою при розриві ПСЗ може привести до підвищення вірогідності травми і розриву трансплантату, внаслідок чого надзвичайно важливим $€$ пошук шляхів поліпшення фрункції рецепторів після оперативного відновлення ПСЗ.

Хоча на сьогодні проведено велику кількість досліджень, присвячених науково-практичним питанням застосування відновлювальних засобів у ранній післяопераційний період при ушкодженнях колінного суглоба, вони ще не повністю задовольнили фрахівців практичної медицини.

У ранній післяопераційний період для фіксації колінного суглоба застосовують екстензійний тутор, у подальшому з метою профілактики контрактури колінного суглоба рекомендують використовувати функціональні ортези з бічними шарнірними механізмами, що дозволяють дозовано регулювати рухи в суглобі [2]. 3 метою усунення больового синдрому впродовж трьох діб після оперативного втручання пацієнтам призначають знеболювальні препарати, всі пацієнти отримують курс антибіотикотерапії [2].

Післяопераційне ведення пацієнтів складається зі стандартних процедур: гіпсова іммобілізація або ортезування колінного суглоба на термін 4 тиж., фрізіопроцедури [13]. 3 4-го тижня починається застосування засобів ЛФК для зміцнення м'язів стегна [13]. Повне статичне навантаження на оперовану нижню кінцівку дозволяється через 2 тиж. після операції [13].

Оцінка найближчих і віддалених результатів лікування пацієнтів з пошкодженнями ПСЗ колінного суглоба проводиться на підставі даних суб'єктивної (шкала IKDS) і об'єктивної (100-бальна шкала Lysholm) оцінки фрункціонального стану колінного суглоба, а також за допомогою артрометра КТ-1000 і МРТ-дослідження тощо [13].

За даними літератури [2], частота тромбозу глибоких вен нижніх кінцівок у разі оперативних втручань на великих суглобах досягає 40-60\%, у 10-20\% клінічних спостережень тромби утворюються у напрямку до проксимальних відділів і в 1-5\% випадків виникає тромбоемболія легеневої артерії з летальним результатом [14]. Тому, згідно з рекомендаціями Американської колегії торакальних фрахівців (АРСР), профілактика венозних тромбоемболій проводиться протягом 30-35 днів. Всім пацієнтам рекомендоване післяопераційне ультразвукове ангіосканування судин обох нижніх кінцівок для виключення венозного тромбозу, застосування декомпресійних панчох, піднятого положення нижніх кінцівок і вживання антикоагулянтів (обов'язковий засіб профрілактики тромбозу глибоких вен нижніх кінцівок).

Велике значення для відновлення фрункції суглоба має раннє призначення лікувальної гімнастики, масажу і фрізіотерапії. Після операції інструктори ЛФК навчають пацієнтів стандартної реабілітаційної програми, що включає ізометричне скорочення м'язів, пасивну мобілізацію наколінка, активні рухи стопою. 3 метою розроблення рухів у колінному суглобі, профрілактики розвитку артрофіброзу рекомендують застосовувати вправи з відкритим кінематичним ланцюгом, у тому числі з обтяженням. Після досягнення кута згинання в колінному суглобі $90^{\circ}$ (3-4 тиж. після операції) призначають вправи із закритим кінематичним ланцюгом [2]. 3 другого дня після операції пацієнти ходять за допомогою двох милиць з поступовим переходом до повного навантаження на оперовану кінцівку до 14-го дня після оперативного втручання. Відновлення опорної i 
локомоторної фрункцій нижньої кінцівки зазвичай відбувається через 8-10 міс.

Стандартна реабілітаційна програма корегується залежно від технічних особливостей самого оперативного втручання та біомеханічних параметрів ходьби, які оцінювали за даними подографії. Критеріями позитивної динаміки були тривалість двоопорного періоду циклу кроку і величина переднього поштовху. У $80,4 \%$ пацієнтів до 56-го місяця після аутопластичної реконструкції ПСЗ тривалість двоопорного періоду зменшилася до 0,10 с, а величина переднього поштовху перевищила аналогічний показник інтактної кінцівки, що було хорошим прогностичним критерієм. Якщо тривалість двоопорного періоду циклу кроку була більшою за 0,10 с, а величина переднього поштовху була зниженою (становила менше 70 \% значень інтактної кінцівки), пацієнт користувався додатковими засобами опори під час ходьби на тривалі відстані, і була потрібна корекція реабілітаційного процесу. Фіксація колінного суглоба фрункціональним ортезом з бічними шарнірними механізмами доцільна протягом 6-7 тиж. з подальшим застосуванням спортивного наколінника до одного року після операції.

Таким чином, аналіз програм реабілітації, що існують у більшості провідних центрів світу, показав орієнтацію їх на терміни післяоперативного втручання, а їх тривалість часто залежала від особистого досвіду лікарів цих центрів - від досить тривалої (понад 9 міс.) до так званої агресивної (менше 4 міс.). Також існують більш помірковані програми - тривалістю 6 міс. [9-11]. Тобто більшість реабілітаційних програм тривають досить довго. Процес реабілітації поділяється на ряд послідовних фаз. Це обумовлено стадійністю репаративних процесів в організмі. А дії реабілітаційної служби мають підлаштовуватися саме під них. Одним із найважчих питань є правильне визначення мети реабілітації в кожній із фраз реабілітації. Правильно поставлена мета має бути специфічною, вимірюваною, досяжною і визначеною за часом. В іï постановці беруть участь пацієнт і реабілітолог, згодом її можна використовувати під час оцінки результату відновного лікування. Крім того важливим $€$ визначення мети проведення реабілітації у конкретного пацієнта для відновлення або компенсації втраченої фрункції. Наприклад, після пластики ПСЗ необхідно відновити іiї функцію, а за наявності остаточної нестабільності в суглобі - компенсувати ії [9-11].

У цій ситуації актуальним питанням залишається розроблення програми з декількома послідовними фразами, кожна з яких має власну мету, завдання та відповідні критерії їх виконання, що стають критеріями переходу до наступної фрази. Програма реабілітації, яка складається з ряду послідовних фраз, завдань і критеріїв їх виконання, $\epsilon$ достатньо контрольованою з боку медичного персоналу, легко сприймається хворим. Постановка послідовних досяжних завдань мотивує хворого, особливо при необхідності повернення до значних навантажень у мінімальні терміни. На сучасному етапі програми реабілітації після артроскопічних оперативних втручань на колінному суглобі ґрунтуються на таких принципах реабілітації хворих [9-11]:

1. Раціональне поєднання методів хірургічного та консервативного лікування на всіх етапах медичної реабілітації.

2. Комплексне використання засобів фрізичної реабілітації з урахуванням механізмів їх терапевтичного впливу та патогенетичної спрямованості.

3. Послідовна корекція функціональних порушень відповідно до завдань кожного з етапів лікування.

4. Диореренційоване використання лікувальних засобів залежно від етапу лікування та ступеня статодинамічних порушень.

5. Поєднання лікувальних заходів 3 раціональним ортопедичним режимом (осьове навантаження та іммобілізація).

6. Регулярність курсового лікування засобами фрізичної реабілітації з урахуванням досягнень у кожному з періодів лікування.

7. Поєднання медикаментозного лікування із засобами фрізичної реабілітації.

Реабілітаційна програма має бути створена таким чином, щоб у мінімальні терміни досягти мети кожного з періодів реабілітації при дотриманні всіх обмежень, зумовлених особливостями проведеного оперативного втручання та стадії одужання пацієнта. На практиці це означає, що потрібно обрати такі фрізичні вправи, які в мінімальні терміни дадуть максимальний ефект та не нашкодять тканинам, що перебудовуються.

Незалежно від типу проведеного артроскопічного оперативного втручання на колінному суглобі послідовні завдання в процесі реабілітації будуть однаковими [9]:

1. Захист цілісності внутрішньосуглобових структур колінного суглоба.

2. Створення умов, що сприятимуть відновленню цих структур.

3. Відновлення рухливості колінного суглоба та досягнення повного обсягу рухів.

4. Збільшення сили м'язів.

5. Відновлення пропріоцепції.

6. Підтримка рухової активності. 
7. Збільшення координованості рухів i, поможливості, спритності.

Отже, послідовність фазного відновлення виглядає так [6]:

1 фаза - зняття больового синдрому та запалення, відновлення обсягу рухів у суглобі - відповідає ранній післяопераційній фразі;

2 фаза - відновлення м'язової сили - відповідає фразі відновлення силових показників;

3 фраза - відновлення координації - відповідає фразі фрункціонального відновлення;

4 фаза - відновлення рухових навичок - відповідає фразі підвищених навантажень.

Крім того, для професійних спортсменів необхідна ще одна фраза - повернення до спортивних навантажень, а для хворих зі значними функціональними порушеннями та ушкодженнями - передопераційна фаза. Тривалість фаз буде різною після різних ушкоджень та типів оперативного лікування [9].

\section{Висновки.}

1. Результати аналізу даних літературних джерел свідчать про те, що лікування хворих з внутрішньосуглобовими ушкодженнями необхідно проводити з обов'язковим урахуванням анатомофуннкціональних особливостей, використовувати методи раннього і повноцінного відновлення

\section{Література}

1. Дубров В. Э. Хирургическая коррекция крестообразных и коллатеральных связок коленного сустава в остром периоде травмы (Клинико-экспериментальное исследование): автореф. дис. ... д-ра мед. наук : спец. 14.00.22 «Травматология и ортопедия» / В. Э. Дубров. - М., 2003. $-48 \mathrm{c}$.

2. Карасева T. Ю. Артроскопические технологии лечения больных с нестабильностью коленного сустава / Т. Ю. Карасева, Е.А.Карасев // Гений ортопедии. - 2013. - № 4. - С. 38-43.

3. Козлова Л. В. Основы реабилитации / Л. В. Козлова, С. А. Козлов, Л. А. Семененко. - Ростов н/Д : Феникс, 2004. - 345 с.

4. Левенець В. М. Спортивна травматологія / В. М. Левенець, Я. В. Лінько. - К. : Здоров'я, 2008. - С. 103-144.

5. Малыгина М. А. Эндопротезирование крестообразных связок коленного сустава : автореф. дис. ... д-ра мед. наук : спец. 14.00.22 «Травматология и ортопедия» / М. А. Малыгина. - М., 2001. - 49 с.

6. Методика відновного лікування хворих після артроскопічної реконструкції передньої хрестоподібної зв'язки в ранньому післяопераційному періоді : метод. рек. / укл. І. В. Рой, С. С. Страфун, О. О. Коструб та ін.; НАМНУ, МОЗУ, УЦНМІ ПЛР, ІТО НАМНУ. - К. : ТОВ «ЕТна-1», 2015. $28 \mathrm{c}$.

7. Новоселов К. А. Повреждения и заболевания коленного сустава / К. А. Новоселов, Н. Н. Корнилов, Т. А. Куляба // Травматология и ортопедия. - СПб., 2006. - С. 213-423.

8. Орлецкий А. К. Оперативные методы лечения посттравматической хронической нестабильности коленного сустава : автореф. дис. ... д-ра мед. наук : спец. 14.00.22 «Травматология и ортопедия» / А. К. Орлецкий. - М., 1998. - 38 с.

9. Рой І. В. Розробка підходів до формування критерій-орієнтованої програми реабілітації хворих після реконструкції передньої хрестоподібної зв'язки / І. В. Рой, О. І. Баяндіна, О. А. Костогриз, І. І. Біла, О. А. Горбунов // Травма. - 2013. - Т. 14, № 6. - С. 56-60. пошкоджених структур суглоба, прагнути до підбору відновлювальних операцій, що не вимагають іммобілізації суглоба.

2. Адекватні відновні комплекси, що враховують тип фріксації трансплантату, функціональні особливості ураженої кінцівки й інші чинники, у тому числі ступінь порушення фрункції колінного суглоба, розроблені не для всіх випадків ушкоджень і їх наслідків. На сьогодні взагалі відсутні програми, що враховують тип фріксації використаного трансплантату при артроскопічних оперативних втручаннях. У зв'язку з цим розроблення нових і вдосконалення традиційних програм реабілітації хворих з ушкодженням ПСЗ після артроскопічних оперативних втручань $€$ дуже актуальним завданням.

3. При однотипних оперативних втручаннях можливе розроблення однотипних програм реабілітації. Індивідуальний підхід фрормується саме в процесі визначення типу реабілітаційної програми, шляхом урахування обмежень, зумовлених загальносоматичним станом пацієнта, характером ушкоджень структур суглоба, особливостями їх усунення під час оперативного втручання та власними вимогами хворого професійного і побутового характеру, що визначає перспективи подальших досліджень.

\section{References}

1. Dubrov, V.E. (2003). Hirurgicheskaya korrektsiya krestoobraznyih i kollateralnyih svyazok kolennogo sustava $v$ ostrom periode travmy (Kliniko-eksperimentalnoe issledovanie) [Surgical correction of cruciate and collateral ligaments of the knee joint in the acute period of trauma (Clinical and experimental study)]. Extended abstract of Doctor's thesis. Moscow [in Russian].

2. Karaseva, T.Yu., Karasev, E.A. (2013). Artroskopicheskie tehnologii lecheniya bolnyh s nestabilnostyu kolennogo sustava [Arthroscopic technologies for treatment of patients with knee instability]. Geniy ortopedii - The genius of orthopedics, 4, $38-43$ [in Russian].

3. Kozlova, L.V., Kozlov, S.A., \& Semenenko, L.A. (2004). Osnovy reabilitatsii [Principles of Rehabilitation]. Rostov na Dony: Feniks [in Russian].

4. Levenets, V.M., \& Linko, Ya.V. (2008). Sportivna travmatologiya [Sports traumatology]. Kyiv: Zdorovya [in Ukranian].

5. Malygina, M.A. (2001). Endoprotezirovanie krestoobraznyih svyazok kolennogo sustava [Endoprosthetics of cruciate ligaments of the knee joint]. Extended abstract of Doctor's thesis. Moscow [in Russian].

6. Roy, I.V., Strafun, S.S., Kostrub, O.O. (Eds.) (2015). Metodyka vidnovnogo likuvannya hvoryh pislya artroskopichnoyi rekonstruktsiyi perednioyi hrestopodibnoyi zvyazky v ranniomu pisliaoperatsiynomu periodi [Method of rehabilitation of patients after arthroscopic reconstruction of anterior cruciate ligament in the early postoperative period]. Kyiv: TOV «Etna-1» [in Ukranian].

7. Novoselov, K.A., Kornilov, N.N., \& Kulyaba, T.A. (2006). Povrezhdeniya i zabolevaniya kolennogo sustava [Damage and diseases of the knee joint]. Travmatologiya i ortopediya - Traumatology and orthopedics. Sankt-Peterburg [in Russian].

8. Orletskiy, A.K. (1998). Operativnyie metody lecheniya posttravmaticheskoy hronicheskoy nestabilnosti kolennogo sustava [Operative methods of treatment of post-traumatic chronic instability of the knee joint]. Extended abstract of Doctor's thesis. Moscow [in Russian]. 